\title{
Erratum to: KPT-330, a potent and selective exportin-1 (XPO-1) inhibitor, shows antitumor effects modulating the expression of cyclin D1 and survivin in prostate cancer models
}

Giovanni Luca Gravina ${ }^{1}$, Andrea Mancini ${ }^{1}$, Patrizia Sanita ${ }^{1}$, Flora Vitale ${ }^{1}$, Francesco Marampon ${ }^{1}$, Luca Ventura ${ }^{2}$, Yosef Landesman ${ }^{3}$, Dilara McCauley ${ }^{3}$, Michael Kauffman ${ }^{3}$, Sharon Shacham ${ }^{3}$ and Claudio Festuccia ${ }^{1^{*}}$

Unfortunately, the original version of this article [1] contained a mistake. The word 'survivin' in the title was incorrectly included as 'surviving'. The title has been corrected above and in the original article.

\section{Author details}

${ }^{1}$ Department of Biotechnological and Applied Clinical Sciences, Laboratory of Radiobiology, University of L'Aquila, L'Aquila, Italy. ${ }^{2}$ Pathology Division, San, Salvatore Hospital, L'Aquila, Italy. ${ }^{3}$ Karyopharm Therapeutics, Newton, MA, USA.

Received: 21 December 2015 Accepted: 21 December 2015

Published online: 11 January 2016

\section{Reference}

1. Gravina G, Mancini A, Sanita P, Vitale F, Marampon F, Ventura L. KPT-330, a potent and selective exportin-1 (XPO-1) inhibitor, shows antitumor effects modulating the expression of cyclin D1 and survivin in prostate cancer models. BMC Cancer. 2015;15:941.

\footnotetext{
*Correspondence: claudio.festuccia@univaq.it

1 Department of Biotechnological and Applied Clinical Sciences, Laboratory of Radiobiology, University of L'Aquila, L'Aquila, Italy

Full list of author information is available at the end of the article
}

Submit your next manuscript to BioMed Central and we will help you at every step:

- We accept pre-submission inquiries

- Our selector tool helps you to find the most relevant journal

- We provide round the clock customer support

- Convenient online submission

- Thorough peer review

- Inclusion in PubMed and all major indexing services

- Maximum visibility for your research

Submit your manuscript at www.biomedcentral.com/submit
() Biomed Central 